\title{
In vitro Evaluation of Fungicides and Bioagents against Alternaria raphani Inciting Alternaria Blight of Radish
}

\author{
Monika Gusain and Sanjeev Ravi* \\ Department of Plant Pathology, College of Horticulture, VCSG UUHF, Bharsar, (Pauri \\ Garhwal) Uttarakhand, India \\ *Corresponding author
}

\section{A B S T R A C T}

\section{Keywords}

Radish, Alternaria blight, Alternaria raphani,

Fungicides, Hexaconazole, Bioagents, Trichodermaharzia numandPer cent inhibition

Article Info

Accepted: 18 December 2020 Available Online: 10 January 2021
The effect of fungicides and bioagents on Alternaria blight of radish caused by Alternaria raphani. Effect of six fungicides viz. Mancozeb, Carbendazim, Ridomil-MZ, Copper oxychloride, Propiconazole and Hexaconazoleat $(100,250,500,750$ and $1000 \mathrm{ppm})$ were evaluated to see their efficacy. The observations were recorded Hexaconazole (100\%) maximum mycelium growth inhibition while Copper oxychloride found minimum mycelium growth inhibition i.e. $(21.57,28.88,36.13,45.55$ and $60.17 \%$ ) at all five concentrations. Among three bioagents T.harzianum was found $(60.71 \%)$ maximum per cent mycelium inhibition while minimum was observed in B. cereus $(14.69 \%)$.

\section{Introduction}

Radish (Raphanus sativus L.) is a most important edible root vegetable of the family Brassicaceae, which grown throughout the year, being mostly eaten raw as a crunchy salad and leaves also used. In general, radish contains carbohydrates, vitamins, proteins and dietary fiber. While it also appears in continental cuisine. It grown as companion as well as catch crops in India. Alternaria leaf blight of oilseed brassicas is known to be incited by three species namely Alternaria brassicae (Berk.) Sacc., Alternaria brassicicola (Schw.) Wiltshire., Alternaria raphani Groves and Skolko (Jasalavichet al., 1995; Saharan and Mehta, 2002). Alternaria blight is the most devastating causing yield loss of 35-38\% (Kolte et al., 1987). Meenu and Hundal (2004) reported that seed yield losses due to Alternaria blight in radish is about (46.48\%) and varied from year to year. 
The radish crop is severely affected by Alternaria blight caused by Alternaria raphani during both seed and root crop production. All foliage is full of small, circular spots and very destructive at siliqua formation stage where all floral part, pods peduncle and seeds become black (Mangala $e t$ al., 2006). Tu et al., (2015) they found against A. brassicae i.e. $(60.84,100,100$ and $100 \%)$ at different concentrations viz. $(100,250,500$ and $1000 \mathrm{ppm})$ in Hexaconazole. Khalse et al., (2017) found that against Alternaria leaf spot of cabbage caused by Alternaria brassiace. The bioagents that maximum inhibition of mycelial growth was recorded in $\mathrm{T}_{1^{-}}$Trichoderma harzianum (65.21\%) followed by $\mathrm{T}_{2}$ - Pseudomonas fluorescens $(62.41 \%)$. In present investigation applied fungicides and bio-control agents in a compatible manner for effective management of Alternaria raphani.

\section{Materials and Methods}

The present investigation was conducted in laboratory of the Department of Plant Pathology, College of Horticulture, VCSGUUHF, Bharsar (Pauri Garhwal) Uttarakhand. Alternaria specimen diseased portion along with healthy part of the specimen were cut into small pieces with the help of sterilized scissors and then surface sterilized by immersing in $0.1 \%$ mercuric chloride $\left(\mathrm{HgCl}_{2}\right)$ or $(70 \%)$ ethanol for about 30 seconds. After that, the specimens were washed thoroughly at least three changes of sterilized water and specimen were transferred into Petri plates containing PDA medium and incubated at $25 \pm 1^{\circ} \mathrm{C}$ for 96 hours. Pathogenic isolates from respective host plant species were isolated from the moist chambers as well as on PDA Petri plates. All the isolates were cultured under sterilized conditions in a laminar air flow and incubated at $25 \pm 1^{\circ} \mathrm{C}$ for 4 days till proper growth Shoaib et al., (2017). Culture was purified from single colony appearing on PDA after observed under microscope and maintained on PDA slants at $4^{\circ} \mathrm{C}$ in a refrigerator for further use. The shape and size of conidia/spore arrangement was studied.

In vitro efficacy of fungicides: Six fungicides viz. Mancozeb, Carbendazim, Ridomil MZ, Copper oxy chloride $(\mathrm{CoC})$, Propiconazole and Hexaconazole at five concentrations i.e.100, 250, 500, 750 and $1000 \mathrm{ppm}$ were evaluated using the poisoned food technique (Nene and Thapliyal, 1993).Inoculated plates were incubated at $25 \pm 1^{\circ} \mathrm{C}$ for 96 hours. Average radial mycelia growth in (mm) was calculated, (r) is radius of diameter, per cent mycelium growth inhibition was calculated by formula and mentioned in below.

In vitro efficacy of bioagents: Three bio agents viz. Bacillus cereus, Trichoderma harzianumand Pseudomonas fluorescens were evaluated using dual culture technique (Faheem et al., 2010). The bioagents and the test fungus were inoculated both sides on a single Petri plates containing solidified PDA with five replications for each treatment. Control was also run along with the other treatments. Inoculated plates were incubated at $25 \pm 1^{\circ} \mathrm{C}$ for 96 hours. The radial growth of the colony of bioagents and the pathogen measured in two directions and average radial mycelial growth was recorded. Per cent mycelium growth inhibition was calculated by using the following formula given by Vincent (1947).

Per cent mycelia inhibition $=\frac{\mathrm{C}-\mathrm{T}}{\mathrm{C}} \times 100$

Where,

$\mathrm{C}=$ radial growth in control

$\mathrm{T}=$ radial growth in treatment 
The data obtained and analyzed by using standard statistical procedure in the simple completely randomized design (CRD) with the help of OPSTAT.

\section{Results and Discussion}

\section{Effect of fungicides}

The data recorded and presented in (Fig-1) among all the fungicides Hexaconazole was found most effective with maximum mycelium inhibition (100\%) at all concentration which was followed by Propiconazole (75.86, 100, 100, 100 and $100 \%)$, Mancozeb i.e. (40.14, 52.86,58.13, 100 and $100 \%$ ), Carbendazim and RidomilMZ. Copper oxychloride among all fungicides least effective at all concentrations i.e. $(21.57,28.88,36.13,45.55$ and $60.17 \%)$.

Similar observations also found by Tu et al., (2015) against A. brassicaei.e. (60.84, 100,
100 and $100 \%$ ) at different concentrations viz.(100, 250, 500 and 1000 ppm)in Hexaconazole. Jakatimath et al., (2017) evaluated fungicides against fruit rot of brinjal (A.alternata) and found that increased in all the fungicides when concentrations were increased. Difenoconazole and Tebuconazole were recorded $100.00 \%$ inhibition at all the concentration tested and hence recorded mean inhibition of $100.00 \%$. Propiconazole $(91.25 \%)$ and Carbendazim $(85.41 \%)$ were the next most effective fungicides when mean per cent inhibition was considered. Panwar et al., (2013) tested seven fungicides i.e. mancozeb, tebuconazole, myclobutanil, tricyclazole, metalaxyl + mancozeb, carbendazim and hexaconazole at (0.05, 0.10 and $0.20 \%)$ concentrations, among these three fungicides viz., tebuconazole, myclobutanil and hexaconazole completely inhibited growth of test pathogen at all concentrations.

Fig.1 Effect of fungicides on per cent mycelium growth inhibition of (A.raphani) at different concentration

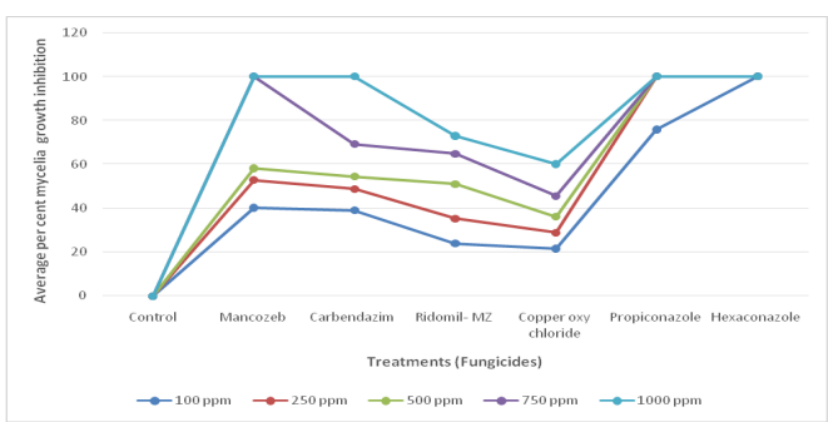

Fig.2 Effect of bioagents on per cent mycelium growth inhibition of (A. raphani).

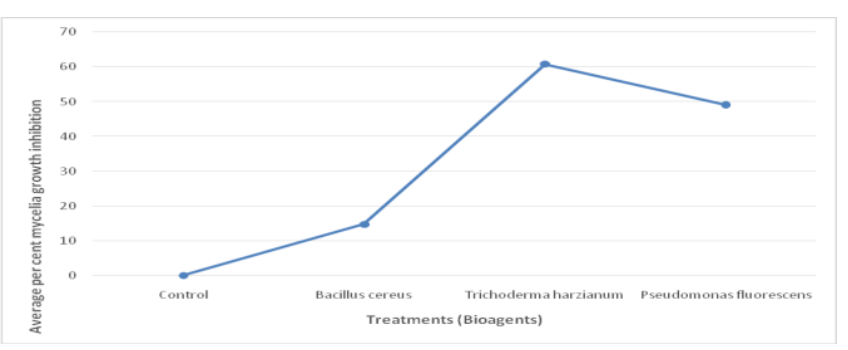




\section{Effect of biocontrol agents}

Effect of three bio-agents were observed and presented in (Fig. 2). Trichoderma harzianum was found $(60.17 \%)$ maximum per cent mycelium growth inhibition followed by Pseudomonas fluorescens (49.07\%) and least inhibition was recorded in Bacillus cereus (14.69\%). Waghe et al., (2015) observed against Alternaria blight, A.helianthi (Hansf) of sunflower; fungal bioagents $T$. harzianum was found most effective and recorded maximum mycelial growth inhibition (72.22\%) followed by $T$. viride $(70.27 \%)$. Bacterial antagonist $P$. fluorescens was found comparatively least effective with $48.60 \%$ inhibition of the test pathogen. Khalse et al., (2017) found that against Alternaria leaf spot of cabbage caused by Alternaria brassiace.

The bioagents, maximum inhibition of mycelial growth was recorded in $T_{1}$ Trichoderma harzianum (65.21\%) followed by $\mathrm{T}_{2^{-}}$Pseudomonas fluorescens (62.41\%). Vivekan and et al., (2018) tested among the biocontrol agents viz. T. harzianum was found more effective with $50.89 \%$ inhibition than $P$. fluorescens against chilli anthracnose, C.capsici. Abbo et al., (2014) Effect of Bacillus spp. (B. subtilis, B. megaterium, $B$. pumilusand $B$. cereus) against early blight ( $A$. alternata) and reported that the promising effect of the four bacteria species tested in reducing disease incidence and severity in comparison with the control.

In conclusion the tested six fungicides at different concentration on the growth of $A$. raphani. Among the fungicides Hexaconazole was found $100 \%$ maximum mycelium growth inhibition while Copper oxychloride was found minimum mycelium growth inhibition. In bioagents Trichoderma harzianum was found most effective while least effective was found in Bacillus cereus.

\section{References}

Abbo, A.S., Idris, M.O. and Hammad, A.M. 2014. The antifungal effects of four Tomato Rhizosphere Bacillus spp. against Alternaria alternata. International Journal of Science and Research (IJSR). 3(7):1324-1328.

Faheem, A., Razdan. V.K., Mohiddin, F.A., Bhat, K.A. and Sheikh, P.A. 2010. Effect of volatile metabolites of Trichoderma species against seven fungal plant pathogens in vitro. Journal of Phytopathology. 2: 34-37.

Jakatimath, S.P., Mesta, R.K., Biradar, I.B., Mushrif, S.K., Ajjappalavar, P.S. 2017. In vitro Evaluation of fungicides, botanicals and bio-agents against Alternaria alternatacausal agent of fruit rot of brinjal. International Journal of Current Microbiology and Applied Sciences. 6 (5): 495-504.

Jasalavich, C.A., Morales, V.M., Pelcher, L.E. and Seguin-Swartz, G.1995. Comparison of nuclear ribosomal DNA sequences from Alternaria species pathogenic to crucifers. Mycol. Res. 99:604-614.

Khalse, K.D., Lal, A.A. and Simon, S. 2017. Efficacy of bio-agents and plant extracts against the Alternaria leaf spot of cabbage (Alternaria brassicae). Journal of Pharmacognosy and Phytochemistry. 6(4):1980-1982.

Kolte, S.J., Awasthi, R.P. and Vishwanath. 1987. Assessment of yield losses due to Alternaria blight in rapeseed and mustard. Indian Phytopathology. 40:209-211.

Mangala, U.N., Subbarao, M. and Ravindrababu, R. 2006. Host range and resistance to Alternaria alternata leaf blight on chilli. Journal of Mycology and Plant Pathology.36(1):84-85.

MeenuandHundal, S.S. 2004. Effect of 
different environments on intensity of Alternaria blight and seed yield of radish crop. J. Agrometeorol. 6:129131.

Nene, Y.L. and Thapliyal, P.N. 1993. Poisoned food technique, Fungicides in Plant Disease Control. $3^{\text {rd }}$ Edn., Oxford\&IBH Publishing Company, Pvt. Ltd, New Delhi. last reprinted 2015.pp.531.

Panwar, V., Yadav, R.S., Singh, H. and Shukla, A.C. 2013. In vitro evaluation of fungicides and bioagents against Alternaria alternata -An incident of leaf spot of Aloe vera. Science and Technology Journal.1(2):19-23.

Saharan, G.S. and Mehta, N.2002.Fungal diseases of rapeseed mustard In: Gupta VK, Paul YS (eds.) Diseases of field crops. Indus Publishing Company, New Delhi. 193-201.

Shoaib, M., Moosa, A., Farzand, A., Sarfraz, M., Ishaq, U. and Ahmad, T. 2017. Postinoculation Application of Fungicides to Manage Alternaria raphanion radish. International Journal of Vegetable Science.24(2):1-10.

Tu, D.V., Somasekhara, Y.M. and Govindaraju, C. 2015. Evaluation of new molecules of fungicides against leaf spot (Alternaria brassicicola (Schw.) Wiltshire) of cabbage (Brassica oleracea var. capitata L.). International Journal of Agricultural Science and Research. 5(3):349-354.

Vincent, J.M.1947.Distrotion of fungal hyphae in the presence of certain inhibitors. Nature. 159:850.

Vivekanand., Ravi, S., Mishra. R.C. and Nautiyal, B.P. 2018. Evaluation of fungicides, botanicals and biocontrol agents against chilli anthracnose caused by Colletotrichum capsici. Plant Disease Research. 33 (1): 64-68.

Waghe, K.P., Wagh, S.S., Kuldhar, D.P. and Panwar, D.V. 2015. Evaluation of different fungicides, bioagents and botanicals against Alternaria blight caused by Alternaria helianthi(Hansf) of sunflower. African Journal of Agricultural Research. 10(5):351-358.

\section{How to cite this article:}

Monika Gusain and Sanjeev Ravi. 2021. In vitro Evaluation of Fungicides and Bioagents against Alternaria raphani Inciting Alternaria Blight of Radish. Int.J.Curr.Microbiol.App.Sci. 10(01): 2726-2730. doi: https://doi.org/10.20546/ijcmas.2021.1001.317 